\title{
Moral and Fictional Discourses on Assisted Reproductive Technologies: Current Responses, Future Scenarios
}

\author{
Maurizio Balistreri • Solveig Lena Hansen
}

Received: 19 November 2019 / Accepted: 28 November 2019/Published online: 11 December 2019

(C) Springer Nature B.V. 2019

\begin{abstract}
This paper gives an introduction to the interdisciplinary special section. Against the historical and ethical background of reproductive technologies, it explores future scenarios of human reproduction and analyzes ways of mutual engagement between fictional and academic endeavors. The underlying idea is that we can make use of human reproduction scenarios in at least two ways: we can use them to critique technologies by imagining terrible consequences for humanity but also to defend positions that favor scientific and technological development.
\end{abstract}

Keywords Human reproductive cloning - Genome editing $\cdot$ Bioethics $\cdot$ Fiction $\cdot$ Narratives $\cdot$ History of medicine

\section{The Special Section}

This special section explores perspectives on new reproductive technologies and genome editing from different fields. In both, academic disciplines (such as bioethics) and fictional narrations (such as literature and film) there is great anticipation for these new technologies, but also

\section{Balistreri \\ Department of Philosophy and Educational Sciences, University of Turin, Turin, Italy}

S. L. Hansen $(\bowtie)$

Department of Medical Ethics and History of Medicine, University Medical Center Göttingen, 37073 Göttingen, Germany e-mail: solveig-lena.hansen@medizin.uni-goettingen.de great concern. It is not always easy to determine what an appropriate reaction to these technologies consists of, because in both professional and popular discourses, moral arguments are often intertwined with narratives of hype and hope or utopian and dystopian scenarios. The aim of our special issue is to deeply analyze such intertwinements from a historical and systematic point of view, and to find new ways of dealing with them.

Through a unique combination of philosophical inquiry, socio-cultural contextualization, historical analysis, and fictional storytelling, this special section maps out the roots and consequences of discussions which started with debates on eugenics, continued with human reproductive cloning and - most recently - have been revived through genome editing. The latter development has initiated discussions that involved scientists themselves, who must balance the technological promises against intergenerational risks that arise from germline interventions, or changes to the structure of society that might lead to the stigmatization or social exclusion of people affected by diseases or disabilities. From a historical perspective we can see resemblances, as similar patterns of arguments were triggered by earlier inventions. For instance, the self-regulatory concern of science was already manifest during events such as the Asilomar conference in 1975. In addition, arguments supporting a need for regulating new avenues of human reproduction were brought forward after events such as the births of Louise Brown in 1978 and Dolly the Sheep in 1996.

While academic debates on these issues have had their trends and turns - often followed by law and policymaking -, science fiction has continuously 
brought individual and collective issues raised by these technologies to public consciousness. Some films and novels often counter scientific facts with stories of vulnerable and affected subjects that address potential risks and side effects, while others explore the potential benefits and transformative possibilities offered by possible future biotechnologies. Even in the absence of an explicit reference to this genre, science fiction seems to be embedded in moral reflection. For instance, some issues that are at the core of bioethical debates remain sci-fi scenarios: cloning a human embryo until full development of an infant, gestating an infant in an artificial environment outside a mother's body, or manipulating a child's genome. The list of topics said to belong more to 'science fiction' than to bioethics is much longer - it includes human enhancement, extreme life extension, brain transplantation, or even cryopreservation of a human body with the hope that resurrection may be possible in the future.

What is the role of speculation and anticipation when we are discussing such future possibilities? On the one hand, if bioethics deals too much with science fiction, it might be accused of losing touch with reality. On the other hand, if bioethics only focuses on the current state of the art, bioethical deliberation may be too late to have an impact before emerging technologies fully arrive. From our point of view, such considerations raise more than mere methodological or epistemic questions. They touch upon moral questions embedded in every kind of bioethical research: To whom do I pay my academic attention? Which groups should I include in my analysis? These questions are deeply intertwined with the construction of futuristic narratives and scenarios, because such groups convey their own historical narratives and perspectives on the respective moral issue. The inclusion or exclusion of these perspectives is contingent not only on everyday social practices and political discourses, but also on the focus of academic endeavors.

The underlying idea of this special section is that we can make use of future scenarios of human reproduction in at least two ways: we can use them to critique technologies by imagining terrible consequences for humanity, or to defend positions that favor scientific and technological development. In both cases these scenarios are not morally neutral; they are constructed based on premises, perspectives, and narrative strategies that all take moral (or social) stances. It is therefore vital to interrogate the scenarios themselves, both in terms of technological feasibility, and their underlying moral commitments.

\section{Human Reproduction: Exploring Future Scenarios}

It is certain that we are faced with technologies that are expected to change human reproduction. Some people anticipate that in the future reproduction and sexuality might be separated even more than they are today, in an era where birth control is in common use. It might be possible for a child to be born without first passing through fertilization, as some scholars emphasize with reference to cloning, i.e. by transferring the nucleus DNA of any somatic cell from a full-grown mammal into an egg cell previously deprived of its nucleus DNA [1-4]. The birth of the sheep Dolly makes it clear that, in animals and under the right conditions, the somatic cells of a body may be induced to develop [5-8] into new individuals. The last 20 years have seen the birth by somatic cloning of a large variety of animals, recently even including monkeys $[9,10]{ }^{1}$

Although reproductive cloning has so far only been used on animals, it could also be employed for human reproduction, e.g. to help those unable to have children sexually or unwilling to turn to donors ([12], 357). Attempting to do so today would be irresponsible, in that cloned animals often display significant genetic anomalies, die prematurely, or may have a life marked by illness and suffering [11, 13, 14]. Yet tomorrow, as some academic advocates of cloning argue, somatic cloning could become as safe as any other reproductive technique. If reproductive cloning were safe enough, they speculate, it would even be preferred by a small minority. Reproductive cloning could also be useful to couples who want to have a biological child but do not have usable gametes ([15], 503): if a man had no sperm or his sperm was not fit for reproduction, he could still father a child by fertilizing his partner's egg cells with the nuclear DNA of his somatic cell. Furthermore, cloning would allow a lesbian couple to have a child without having to resort to a sperm donor: to create an embryo it would be sufficient to transfer the DNA of one partner into the egg cell of the other ([16], 7) - the child would have the nuclear DNA of the former and the

\footnotetext{
${ }^{1}$ Year after year, we have seen a slow increase not only in the number of species cloned but also the ability to produce embryos via cloning and carry on their development up to birth. Dolly was the only animal born from 277 embryos produced by transferring nucleus DNA (about $0,36 \%$ ), whilst today the success rate of the intervention - defined as the proportion of transferred embryos that reach birth - is around 2-3\% for all species considered. In cattle the average is far higher, oscillating between 5 and $20 \%$, whereas it is only around 6\%, in pigs [11].
} 
mitochondrial DNA of the latter. Women could thus have a child by themselves by combining one of their skin cells with one of their unfertilized egg to be placed back into their uterus $([17], 117)$.

Moreover, in the future, it may be possible to create an embryo to use for reproduction through parthenogenesis, i.e. using an egg cell without the need for the spermatozoid; electrically or chemically stimulating the egg may be sufficient to it split like an embryo. To date, unfertilized eggs have been used to obtain mouse, rabbit, sheep, pig, bull and monkey embryos [18] - and even human embryos ('parthenotes') [19]. However, "(n)o one has been able successfully to make mammals through parthenogenesis, or even get as far as establishing a pregnancy. One common explanation is that, in mammals, successful embryonic development may require some genes that have male imprinting" ([20], 134). So this research, at the moment, is speculative.

At the current state of development, the aim of research on parthenogenesis is to isolate embryonic stem cells, i.e. cells able to differentiate themselves into any cell type [21-23]. We already know that gamete precursors can be obtained from such embryonic stem cells [24]. Now we know that the same result can also be obtained starting from a somatic cell, through the creation of induced pluripotent stem cells (iPSCs) ([4, 25], 69). In this case, we face not so much speculation about, as anticipation of, a new technology. The scenario includes the idea that every person could be fertile until death [26] since they could always use in vitro or artificial gametes to reproduce. Today, after menopause, women can only have a biological child if they have frozen their egg cells, ovary tissue, or embryos. If it was possible to produce in vitro gametes from somatic cells, post-menopausal women would be able to have a biological child without prior planning [25, 27].

Moreover, this scenario includes the striking idea that each of us could have gametes of both sexes, because the egg cells could be obtained from male cells and sperm from female cells $[28,29] .^{2}$ This means that same-sex couples could have children without needing a gamete donor. Furthermore, women wanting to have a child by themselves could use sperm produced from their own somatic cells. Men could obtain the same result as well; however, until there is artificial womb, they would still need a woman to carry the pregnancy

\footnotetext{
$\overline{2}$ Studies on animals show, for instance, that generation from two female cells and two male cells is possible [30].
}

for them. It is true that reproduction between close relatives raises the risk of harmful genetic mutations and consequently the risks will probably be greater if a person reproduces with their own in vitro gametes [28]. Here, proponents argue that screening programs allow the identification and rejection of embryos, or even just the gametes, that display genetic anomalies [31].

Further, the use of in vitro gametes would let more than two people have a biological child together, in that two people may produce an embryo, develop embryonic stem cells and then gametes usable to produce another embryo with the gametes of a third person [32]. It has been suggested that same-sex couples in particular may have more chances to derive gametes from embryos that were created by fertilization rather than through SCNTESCs or iPSCs; a method which "is presumably less complicated and less risky" ([33], 689). In that case, the embryo would have the genetic traits of three people: If Pablo and Maria produced an embryo, sperm could be obtained from this embryo that could be used to produce an embryo with Ingrid's eggs. Thus, some would argue, the baby would have the genes of Pablo, Maria and Ingrid. Others would say that the baby has the genes of Pablo and Maria's embryo and Ingrid's eggs. The more people who are interested in having shared biological parenthood, the more times this intervention would be repeated - at least theoretically, there is no limit to the number of people who could be involved ([15, 29, 34, 35], 501-502).

For now, pregnancy can only occur in women's bodies. In the future, it might be possible to conceive a human embryo in a laboratory and use an artificial uterus to carry the embryo up to the birth of a new individual. Although producing an artificial uterus does not seem easy, some maintain that the difficulties would not be insurmountable, and thus ectogenesis could be a future option [36]. Researchers in some countries, like the UK, are now able to grow a human embryo in the laboratory up to the thirteenth day after conception [37-39]. Technically, even growing it for 20 days would not be a problem. Legally, however, researchers are not allowed to do this (due to the 14day rule of the Human Fertilization and Embryology Authority, HFEA).

Already doctors have the ability to keep a prematurely born fetus alive from the 23rd week, although in these cases the surviving child is rarely free from serious brain damage. This means that in order for an artificial uterus to carry a full-term pregnancy, the 
time span between the thirteenth day and the 23rd week currently represents the most difficult challenge. Artificial gestation could therefore come about as result of gradual improvements in neonatal intensive care [40]. Ectogenesis would ensure equal opportunity in human reproduction [41]. Men could also be free to have a child when they most preferred it, and women who preferred it could have a child without being pregnant. There are couples who consider pregnancy and birth to be a wonderful, indispensable experience, whilst others would happily forego it, for example because they do not want to experience months of nausea and insomnia or change their lifestyle [42, 43].

Finally, today our genetic heritage is determined by chance, but in the near future people may be able to choose it. Genetic interventions in the development of embryos could not only correct or prevent significant genetic anomalies but also produce children who are healthier and more resistant to disease. Getting to this point would require experimenting on embryos, which is still ethically and politically controversial. However, should this technology become safe and reliable, people could apply it successfully every time they desire to reproduce [20]. With this technology in particular, we are not talking about science fiction scenarios but about future possibilities that appear to be nearing: He Jiankui, a Chinese scientist, has already claimed to have created the first genetically edited children [44].

In its initial stages, human subject research on germline genome editing could be aimed at the development of interventions to prevent or reduce the risk of transmitting genetic anomalies to offspring. For certain couples who cannot produce healthy embryos, germline genome editing may be the only way for them to avoid passing on genetic disorders ([45], 500; [46, 47]). ${ }^{3}$ Yet as germline genome editing techniques develop, some speculate

\footnotetext{
${ }^{3}$ Even now, a couple turning to an assisted reproduction intervention may decide which embryo to give birth to, bearing in mind the results of a prenatal genetic diagnosis on the fetus or preimplantation on the embryo, hence assessing the genetic features of the embryos produced in vitro [47]. This procedure is mainly offered when there is a risk of transmitting serious genetic anomalies to the unborn child [16], but it can also be used (for example in USA, Israel, Cyprus and Ukraine) to select the sex of the future child for family balancing ([48], 77). A couple, aware they could transmit genetic anomalies to the future child and eager to avoid the risk of an abortion, could prefer to turn to assisted reproduction involving PND and PGD.
}

about the unprecedented chance to shape the genetic code of children and eventually, influence the genetic makeup of future generations ([20], 299; [49]). People may then seek not only to correct but even to enhance the genes of their future children. ${ }^{4}$

Proponents of pushing forward with such technologies, like $\mathrm{He}$, argue that they could have potential positive impacts on the treatment of diseases, such as HIV. However, as Savulescu and Singer [49] underline, this attempt "was unethical, not because it involved gene editing, but because it failed to conform to the basic values and principles that govern all research involving human participants". This statement illustrates an important, yet often marginalized, point in debates on the future of reproduction. When put into practice, these technologies need to be tested - and not only in animals but in humans, involving clinical trials. However, in order to proceed with such trials, researchers not only need to ensure the consent of the subjects [55] but also demonstrate that no less risky options for treatment exist [56].

With regard to some of these examples, particularly those that venture into more speculative territory, the question can be raised why some scholars continuously devote their attention to technologies that are unlikely ever to be included in clinical practice. From a critical perspective that takes into account the function of such narratives, the obvious hypothesis is the following: academic and fictional discourses not only offer a moral perspective, they also deal with the 'hype and hope' of these technologies garnering attention. Again, this desire for attention and sensation might be inherently morally problematic if it leads to skewed perspectives that prematurely welcome future technologies by ignoring the practical steps necessary to achieve safe procedures for those affected and the consequences of failing to do so.

\section{The Relationship between Bioethics and Science Fiction}

All the technologies described here share one important feature: in nature, human reproduction occurs sexually,

\footnotetext{
${ }^{4}$ In even more speculative discussions on moral enhancement, scholars anticipate that physical and cognitive abilities of humans are subject to fatigue. Empathy is particularly limited and mainly directed towards those belonging to one's restricted circle [50, 51]. Natural selection could of course lead here to changes as well, but they could be obtained much faster by modifying or enhancing the genome of future generations, as some scholars suggest [52-54].
} 
with the fertilization of the egg cell by the spermatozoid. New reproductive technologies have already deeply changed the idea of human reproduction, and the mere fact that these technologies appear unnatural does not provide sufficient reason to consider them unacceptable. Adjectives like 'unnatural' are often thrown about to denigrate those who are different and hardly ever help in promoting deeper discussions. Although we often value human nature for anthropological and moral reasons, in democratic societies we usually also respect different 'Menschenbilder' (conceptions of humanity; more literally, 'images of the human being'). Further, it is impossible, to use the natural as the final criterion to discriminate that which is ethically acceptable and that which is clearly immoral. First, it is actually not so obvious that new reproductive technologies are not natural, in that the definition of what is natural and what is not is a complex philosophical issue. As David Hume remarked, if we define what is natural, we can consider as natural "every event, which has ever happen'd in the world, excepting those miracles, on which our religion is founded" ([57], 304). But if we pit 'natural' against what is rare and unusual, "and in this sense of the word, which is the common one, there may often arise disputes concerning what is natural or unnatural, and one may in general affirm, that we are not possess'd of any precise standard, by which these disputes can be decided" ([57], 304-5).

Today, we are amazed at the idea that tomorrow's children might be born from somatic cells (by cloning) or in vitro gametes. In addition, the surprise is even greater when they think that in the future children will be born in artificial wombs and be subjected to genetic engineering. Others reject from the same ideas. Indeed, these scenarios above may foster fear because "every thing that is unexpected affrights us. The suddenness and strangeness of an appearance naturally excite a commotion in the mind, like every thing for which we are not prepar'd, and to which we are not accustom'd" ([57], 285). Surprise is pleasurable in itself, though, as Hume said, "it puts the spirits in agitation, it not only augments our agreeable affections, but also our painful" ([57], 271). Furthermore, worries regarding new reproductive technologies are probably also based on a psychological tendency of humans to prefer that which preserves the status quo [58]. The "favourable prejudice towards the status quo is endemic in human cognition" as Bostrom and Ord [59] argue.
However, others argue that the status quo is already inherently morally problematic and the challenges, thus, will be increased by new technologies. They anticipate that such technologies may not ameliorate but rather magnify the problems of the status quo - whether in terms of the inegalitarian social dynamics of reproduction or the failure of current societies to put into practice ethical principles such as justice. It has been maintained, for instance, that some reproductive technologies would be incompatible with the principles of a liberal order and would perpetuate social inequality [60]. Furthermore, it has been argued that these technologies would violate the basic right to having a non-manipulated genetic heritage and condemn the person coming into the world to live a life that others had already lived or planned [61].

From this starting point, it can be said that there are two different perspectives on the relationship between ethics and speculative scenarios: a confirmative and a critical perspective. Science fiction, as we understand it, is one amongst many forms to dive into such speculation. Accordingly, when using science fiction scenarios, researchers make a choice between the confirmative and the critical perspective.

On the one hand, science fiction may help us face future reproductive scenarios by making them more 'familiar'. After all, when something frequently repeats itself, Hume wrote, the novelty fades [57]; passions calm, agitation in the soul placates itself, and we observe things much more peacefully. Thus, even if society cannot accept new reproductive technologies overnight, it is reasonable to assume that over time people will grow accustomed to these new possibilities that are now on the horizon and recognize, slowly but surely, their value for humanity. From a perspective of science fiction as confirmation, these stories can put us in a better position to understand the advantages of new reproductive technologies more clearly and objectively. Georg W.F. Hegel stated that philosophy is like the owl of Minerva, which only takes flight when the day is over. If we take this view seriously, philosophy should only reflect on events and actions that have already occurred. However, this might be too late. Looking ahead and projecting ourselves into future scenarios is the task of science fiction, which tries to foresee what is waiting on the horizon. In this way, it reverses the classical hierarchy that sees literature as the handmaiden of serious reflection; philosophical reflection often puts science fiction writers in the position to imagine the moral 
implications emerging with new reproductive technologies [62]. However, moral and social issues that concern these technologies are often first presented in science fiction and only later discussed in philosophy [63].

On the other hand, science fiction may take the position of critique, helping to construct a moral standpoint regarding the impact of technology on our society and on our lives that will sway our moral reflection. The stories portrayed in films and novels replace hard scientific facts with touching stories about individuals, with all their vulnerabilities and hopes. Often in bioethical reflection, the space for reasoning about individual and concrete cases is too marginal to offer an exhaustive picture of the situation lived by the characters described. In the tradition of casuistry [64], science fiction can provide a counter discourse to an exaggerated enthusiasm for reproductive technologies. The length of the story allows the reader to get closer to the narrated events, to have privileged access to the characters, and to know their psychology and their motivations. In this way, science fiction can also provide us with important information on actual new technologies and the world around us. But its value is in its ability to trigger our empathy and imagine other lives, other 'existences'.

These stories, through their social critique, are often counter narratives, i.e., of opposition "not only to dominant narratives, but also to prevailing modes of [...] thought and methods of research" ([65], 52). As Squier has argued, as soon as technologies are "normalized" and academics "lose awareness" ([66], 4) of them, science fiction begins to embed them in stories of social relationality and vulnerability. No other genre offers as much imaginative leeway to portray confrontations with new kinds of biotechnology and the beings that result from it. Consequently, the genre is multiply intertwined with 'the ideology of progress' ([67], 29). From a cultural-historical perspective, it does not seem to be a coincidence but rather a result of a deeply felt demand to negotiate potential consequences, side effects, and risks that, especially in such a technically highly advanced culture, technical progress is fictionally reshaped and thereby processed. Notably, the UK is not only famous for the tradition of scientific experiments but also for its variations of utopias and science fiction, such as Mary Shelley's Frankenstein (1818) or Aldous Huxley's Brave New World (1932), to name but two prominent examples. Technologies such as IVF and mammalian cloning were developed in Britain, in the cultural context in which debates about the future of human reproduction were first explored by scientists, novelists, and public intellectuals.

\section{Mutual Invitations of Academic and Fictional Debates}

Clearly, the relationship between bioethics and science fiction is complex. Science fiction can contribute to confirming our hopes about new reproductive technologies. It can help us overcome significant, deeply rooted prejudices and enable us to grow accustomed to future scenarios. But literary discourse can also construct narratives based on different moral premises. For example, it can point out that not everyone will equally profit from the scientific achievements presented in these scenarios. In both cases, science fiction can contribute to bioethical discourses with new perspectives and arguments. Such stories give us privileged access to the world of tomorrow, with the closeness and focus on subjectivity found in science fiction. Nevertheless, such stories are not morally neutral. On the contrary, they are inherent to moral discourses.

This special section has invited scholars from various fields to 'tell their stories' - to give their perspectives on new reproductive technologies relative to their backgrounds. It features four Original Research Papers (by Robert Ranisch, Oliver Feeney, Aline Ferreira and one co-authored by Fabrizio Rufo and Antonella Ficorilli), two Discussion Notes (by Ari Schick and Mirko Garasic), and two Art-and-Science Interaction articles (one co-authored by Julia Diekämper and Solveig Lena Hansen, and the English translation of a short story by Francesco Verso). ${ }^{5}$

Robert Ranisch's paper, entitled 'Eugenics is back'? Historic References in Current Discussions of Germline Gene Editing traces the history of eugenics in relation to the present discourse on germline genome editing. It identifies seven variants of eugenics arguments in bioethics and analyzes how scholars make use of narratives of the past to justify their positions in the present. The articles concludes that references to the eugenic past used to rebut gene editing are highly selective and should be abandoned in favor of a more scientific and transparent discourse.

\footnotetext{
5 The special section is an outcome of our conference 'What's Next?'. Hype and Hope from Human Reproductive Cloning to Genome Editing, kindly supported and funded by the Andrea von Braun Stiftung, Munich, Germany.
} 
Fabrizio Rufo and Antonella Ficorilli do not go back as far in history as the beginning of eugenics, but they also feature a historical storyline. In their paper, From Asilomar to Genome Editing: Research Ethics and Models of Decision, they compare the 1975 Asilomar conference on recombinant DNA with the 2015 conference in Napa on human germline engineering and events following this conference. They observe three shifts that have occurred over those forty years: First, biology as a discipline of observation has transformed into biology as intervention. Second, the awareness amongst scientists that they need to discuss moral questions, risks and consequences of their research, has risen. Third, the process of discussion and deliberation has moved from a hierarchical approach to a reticular conception of knowledge.

Also taking a comparative perspective, Oliver Feeney's article Editing the Gene-Editing Debate: ReAssessing the Normative Discussions on Emerging Genetic Technologies analyses the mapping of the human genome in relationship to recent discussions on CRISPR-Cas9. From a critical perspective, the paper states that dominant normative frameworks (in academia and policy) are insufficient for evaluating new technologies such as CRISPR. They often build on misleading genetic essentialist assumptions and try to find answers to questions that are too abstract and speculative, such as human enhancements. Accordingly, Feeney advocates for a reframing of the debate and policy with more sociological insight.

The contribution by Aline Ferreira, entitled New Bodies, New Identities? The Negotiation of Cloning Technologies in Young Adult Fiction analyzes reproductive cloning in young adult fiction. Comparing literary and academic discourses, the paper analyzes the idea of cloned bodies for 'housing' the consciousness of persons for the aim of therapy and life extension. The paper argues that speculative bioethics should start to take these literary perspectives into account because these novels and films point out the uniqueness of clones, depicting them as usual humans in search of an identity.

Mirko Garasic's Discussion Note, Altered Mortality: Why the Quest for Immortality is Regaining Visibility in the Media also focuses on the notion of separation of body and consciousness. It analyzes the TV series Altered Carbon in relation to a 'quasi-manifesto' on head transplants in 2017. It points out how an announced scientific experiment and the cinematographic discourse are interlinked, and concludes that in this case, the fictional series serves to confirm the expert discourse. Against the background of hyper-individualism, the discussion note critically argues mortality should be taken into account in collective discussions.

Ari Schick's Discussion Note, What Counts as 'Success' in Speculative and Anticipatory Ethics? Lessons from the Advent of Germline Gene Editing critically asks how we should (and should not) pursue speculative ethics. Taking genetic engineering as an example, the commentary notes the transition from the 'speculative' mode of early bioethics to the 'anticipatory' turn of the 1990s. Attempting to continually move the focus on the discourse on genetic engineering ahead, absent significant developments in clinical applications, Schick argues, risks not providing a particularly useful anticipatory evaluation of future technologies and may undermine existing norms long before a broad consensus would justify moving beyond them.

Julia Diekämper's and Solveig Lena Hansen's Artand-Science Interaction article, entitled Hype, Hope, and Help: Situating a Science Announcement in a Web of Stories, analyzes He Jiankui's announcement of Lulu and Nana. Against the background of literary and cultural theories, the analysis compares this medial YouTube-story with narratives employed in fictional stories. Because no other sources are yet available such as raw genetic data, peer review publications, or testimony from the parents - his story actually performs the evidence of its own success through a narrative stance that exposes itself as highly self-centered.

Finally, Francesco Verso's short story Two Worlds, the second Art-and-Science Interaction article in this issue, provides a fictional contribution to the special section. In his scenario, genetic engineering has been widely pursued on Earth, resulting in chimeras. Paralleling this, the story describes the consequences of climate change in the future and how new species try to recolonize Earth with a diversity of florae. As so many science fiction scenarios, this can be read not only as an extrapolation into the future but as a comment on the present - in this case the debate on climate change.

Acknowledgements Both authors thank the Andrea von Braun Stiftung (Munich, Germany) for financial support of the conference 'What's Next?' Hype and Hope from Human Reproductive Cloning to Genome Editing, July 2017, in Torino, Italy. Solveig L. Hansen thanks the Department of Medical Ethics and History of Medicine (Goettingen, Germany) for supporting her independent research. 


\section{References}

1. Devolder K (2013) Were it physically safe, human reproductive cloning may be permissible. In: Caplan A, Arp R (eds) Contemporary debate in bioethics. Wiley-Blackwell, Malden, pp 79-89

2. Harris J (2014) Time to exorcise the cloning demon. Camb Q Healthc Ethics 23:53-62

3. Macintosh KL (2014) Human cloning: four fallacies and their legal consequences. Cambridge University Press, Cambridge

4. Segers S, Pennings G, Dondorp W, de Wert G, Mertes H (2019a) In vitro gametogenesis and reproductive cloning: can we allow one while banning the other? Bioethics 33:6875

5. Boiani M (2013) Cloned human ES cells: a great leap forward, and still needed? Mol Hum Reprod 19(10):629633

6. Chung YG, Eum JH, Lee JE, Shim SH, Sepilian V, Hong SW, Lee Y, Treff NR, Choi YH, Kimbrel EA, Dittman RE, Lanza R, Lee DR (2014) Human somatic cell nuclear transfer using adult cells. Cell Stem Cell 14:777-780

7. Cibelli JB (2014) Human somatic cell nuclear transfer is alive and well. Cell Stem Cell 14:699-701

8. Tachibana M, Amato P, Sparman M, Gutierrez NM, Tippner-Hedges R, Ma H, Kang E, Fulati A, Lee HS, Sritanaudomchai H, Masterson K, Larson J, Eaton D, Sadler-Fredd K, Battaglia D, Lee D, Wu D, Jensen J, Patton P, Gokhale S, Stouffer RL, Wolf D, Mitalipov S (2013) Human embryonic stem cells derived by somatic cell nuclear transfer. Cell 153(6):1228-1238

9. Liu Z, Yijun C et al (2018) Cloning of macacque monkey by somatic cell nuclear transfer. Cell 172(4):881-887e7

10. Qiu P, Jiang J et al (2019) BMAL1 knockout macaque monkeys display reduced sleep and psychiatric disorders. Natl Sci Rev 6(1):87-100

11. EFSA (2012) Update on the state of play of animal health and welfare and environmental impact of animals derived from SCNT cloning and their offspring, and food safety of products obtained from those animals. EFSA J 10(7): 2794(42 pages)

12. Smajdor A, Cutas D (2017) 'I am your mother and your father!' In vitro derived gametes and the ethics of solo reproduction. Health Care Anal 25(4):354-369

13. Schmidt M, Kragh PM, Li J, du Y, Lin L, Liu Y, Bøgh IB, Winther KD, Vajta G, Callesen H (2010) Pregnancies and piglets from large white sow recipients after two transfer methods of cloned and transgenic embryos of different pig breeds. Theriogenology 74:1233-1240

14. Watanabe S, Nagai T (2011) Survival of embryos and calves derived from somatic cell nuclear transfer in cattle: a nationwide survey in Japan. Anim Sci J 82:360-365

15. Segers S, Pennings G, Dondorp W, de Wert G, Mertes H (2019b) In vitro gametogenesis and the creation of 'designer babies'. Camb Q Healthc Ethics 28:499-508

16. Cavaliere G, Palacios Gonzáles C (2018) Lesbian motherhood and mitochondrial replacement techniques: reproductive freedom and genetic kinship. J Med Ethics 44:835-842

17. Silver LM (1997) Remaking Eden. Cloning and beyond in a brave new world. Avon Books, New York
18. Jose de Carli G, Campos Pereira T (2017) On human parthenogenesis. Med Hypotheses 106:57-60

19. Brevini TA, Gandolfi F (2008) Parthenotes as a source of embryonic stem cells. Cell Prolif 41(Suppl 1):20-30

20. Greely HT (2016) The end of sex and the future of human reproduction. Harvard University Press, Cambridge, MA

21. Bos-Mikich A, Bressan FF et al (2016) Parthenogenesis and human assisted reproduction. Stem Cells Int., Article 1970843 (8 pages). https://doi.org/10.1155/2016/1970843

22. Daughtry B, Mitalipov S (2014) Concise review: parthenote stem cells for regenerative medicine: genetic, epigenetic, and developmental features. Stem Cells Transl Med 3:290-298

23. Gills-Buck EM (2016) Redefining 'virgin birth' after Kaguya: mammalian parhenogenesis in experimental biology, 2004-2014. Catalyst: Feminism, Theory, Technoscience 2(1):1-67

24. Irie N, Weinberger L et al (2014) SOX17 is a critical specifier of human primordial germ cell fate. Cell 160:253-268

25. Smajdor A, Cutas D (2015) Artificial gametes. Report for Nuffield Council on Bioethics. https://nuffieldbioethics. org/wp-content/uploads/Background-paper-2016-Artificialgametes.pdf. Accessed 7 December 2019

26. Bredenoord AL, Hyun I (2017) Ethics of stem cell-derived gametes made in a dish: fertility for everyone? EMBO Molecular Medicine 9(4):396-398

27. Cutas D, Smajdor A (2015) Postmenopausal motherhood reloaded: advanced age and in vitro derived gametes. Hypatia 30(2):386-402. https://doi.org/10.1111/hypa.12151

28. Cutas D, Smajdor A (2016) I am your mother and your father! In vitro derived gametes and the ethics of solo reproduction. Health Care Anal 25(4):354-369. https://doi. org/10.1007/s10728-016-0321-7

29. Palacios-Gonzáles C, Harris J, Testa G (2014) Multiplex parenting: IVG and the generations to come. J Med Ethics 40(11):752-758

30. Li Z-K, Wang L-Y, Wang LB, Feng GH, Yuan XW, Liu C, Xu K, Li YH, Wan HF, Zhang Y, Li YF, Li X, Li W, Zhou Q, Hu BY (2018) Generation of bimaternal and bipaternal mice from hypoethylated haplois ESCs with imprinting region deletion. Cell Stem Cell 23(5):665-676e4

31. Suter SM (2015) In vitro gametogenesis: just another way to have a baby? J Law Biosci 3(1):87-119

32. Sparrow R (2014) In vitro eugenics. J Med Ethics 40(11): 725-731

33. Segers S, Mertes H, Pennings G, de Wert G, Dondorp W (2017) Using stem cell-derived gametes for same-sex reproduction: an alternative scenario. J Med Ethics 43:688-691

34. Sparrow R (2012) Orphaned at conception: the uncanny offspring of embryos. Bioethics 26(4):173-181

35. Watt A (2014) Ancestor embryos: embryonic gametes and genetic parenthood. J Med Ethics 40(11):759-761

36. Limon C (2016) From surrogacy to ectogenesis: reproductive justice and equal opportunity in neoliberal times. Aust Fem Stud 31(88):203-219

37. Deglincerti A, Croft GF, Pietila LN, Zernicka-Goetz M, Siggia ED, Brivanlou AH (2016) Self-organization of the in vitro attached human embryo. Nature 533(7602):251-254

38. Rossant J (2016) Implantation barrier overcome. Nature 533:182-183

39. Shahbazi MS, Jedrusik A, Vuoristo S, Recher G, Hupalowska A, Bolton V, Fogarty NNM, Campbell A, 
Devito L, Ilic D, Khalaf Y, Niakan KK, Fishel S, ZernickaGoetz M (2016) Self-organization of the human embryo in the absence of maternal tissues. Nat Cell Biol 18(6):700710

40. Romanis EC (2018) Artificial womb technology and the frontiers of human reproduction: conceptual differences and potential implications. J Med Ethics 44:751-755

41. Kendal E (2015) Equal opportunity and the case for state sponsored Ectogenesis. Palgrave Macmillan, London

42. Blackshaw BP, Rodger D (2019) Ectogenesis and the case against the right to the death of the foetus. Bioethics 33:76-81

43. Räsänen J (2017) Ectogenesis, abortion and a right to the death of the fetus. Bioethics 31:697-702

44. Cyranoski D, Ledford H (2018) International outcry over genome-edited baby claim. Nature 563(7733):607-608

45. Gyngell C, Douglas T, Savulescu J (2017) The ethics of germline gene editing. J Appl Philos 34(4):498-513

46. Cavaliere G (2017) Genome editing and assisted reproduction: curing embryos, society or prospective parents. Med Health Care and Philos 2:215-225. https://doi.org/10.1007 /s11019-017-9793-y

47. Ranisch R (2019) Germline genome editing versus preimplantation genetic diagnosis: is there a case in favour of germline interventions? Bioethics, accepted 25 June 2019 (10 pages)

48. Kudina O (2019) Accounting for the moral significance of technology: revisiting the case of non-medical sex selection. Bioeth Inq 16:75-85

49. Savulescu J, Singer P (2019) An ethical pathway for gene editing. Bioethics 33(2):221-222

50. Persson I, Savulescu J (2012) Unfit for the future. Oxford University Press, Oxford

51. Rakić V (2019) Genome editing for involuntary moral enhancement. Camb Q Healthc Ethics 28:46-54

52. Agar N (2019) Why we should defend gene editing as eugenics. Camb Q Healthc Ethics 28:9-19

53. Cwik B (2019) Moving beyond 'therapy' and 'enhancement' in the ethics of gene editing. Camb Q Healthc Ethics 28:695-707
54. Harris J (2007) Enhancing evolution. Princeton University Press, Princeton

55. Brock DW (2008) Philosophical justifications of informed consent in research. In: Emanuel EJ et al (eds) The Oxford textbook of clinical research ethics. Oxford University Press, Oxford, pp 606-612

56. King NMP, Churchill LP (2008) Assessing and comparing potential benefits and risks of harm. In: Emanuel EJ, Grady CG, Crouch RA, Lie RK, Miller FG, Wendler DD (eds) The Oxford textbook of clinical research ethics. Oxford University Press, Oxford, pp 514-526

57. Hume D (2000) A treatise of human nature (ed. by David F. Notyon and Mary J. Norton). Oxford University Press, Oxford

58. Samuelson W, Zeckhauser R (1988) Status quo bias in decision making. J Risk Uncertain 1:7-59

59. Bostrom N, Ord T (2006) The reversal test: eliminating status quo bias in applied ethics. Ethics 116:656-679

60. Habermas J (2003) The future of human nature. Cambridge Polity Press, Cambridge

61. Nussbaum M (2004) Hiding from humanity, disgust, shame, and the law. Princeton University Press, Princeton

62. Ferreira A (2004) I am the other: literary negotiations of human cloning. Praeger Pub Text, Santa Barbara

63. Turney J (1998) Frankenstein's footsteps: science, genetics and popular culture. Yale University Press, New Haven

64. Jonsen AR, Toulmin S (1998) The abuse of casuistry: a history of moral reasoning. University of California Press, Berkeley

65. Gallagher C, Greenblatt S (2000) Practicing new historicism. The Chicago University Press, Chicago

66. Squier SM (2004) Liminal lives: imagining the human at the frontiers of biomedicine. Duke University Press, Durham

67. Rieder J (2008) Colonialism and the emergence of science fiction. Wesleyan University Press, Middletown

Publisher's Note Springer Nature remains neutral with regard to jurisdictional claims in published maps and institutional affiliations. 